\title{
Social Marketing and Consumer Awareness of NGOs Activities
}

\author{
Virender Kumar*, Monika saini**, Pawan Kumar*** \\ *Project Fellow, Major Research Project (UGC) \\ ** Research Scholar \\ ***Research Scholar \\ Deptt. Of commerce Kurukshetra University, Kurukshetra
}

\begin{abstract}
Social marketing is a process for influencing human behavior on a large scale, using marketing principle for the purpose of societal benefit rather than commercial profit. People, organizations and government are experiencing new innovations of technology. The development of this technology can greatly support NGOs work through social media. The term NGO is broad and ambiguous. It covers a range of organizations within civil society, from political action groups to sports clubs. This study has been conducted to know the concept of social marketing and consumer awareness of NGOs activities. Sample of 200 respondents has been taken from the three districts of Haryana. Results reveal that respondents are mostly aware about the NGOs. And major source of information about NGOs activities is direct information from NGOs.
\end{abstract}

\section{Introduction}

Social marketing is a process for influencing human behavior on a large scale, using marketing principle for the purpose of societal benefit rather than commercial profit. Commercial marketing usually urges an exchange of money for the goods and services. Social marketing usually asks an audience to change its practices in return for something of value. The central challenges of any social marketing program is to establish an exchange which satisfy both marketer's needs and the target audience's wants in addition to producing an overall societal benefit.

People, organizations and government are experiencing new innovations of technology. The development of this technology can greatly support NGOs work through social media. Online social networking has become a popular work tool among NGOs. These organizations are increasingly embracing social networks in order to promote awareness, recruit followers and raise money (moshman,j).

Kotler and Andreason define social marketing as "differing from other areas of marketing only with respect to the objectives of the marketers and his or her organization. Social marketing seeks to influence social behavior, not to benefit the marketer, but to benefit the target audience and general society". Social marketing is used extensively in international health programs, especially for contraceptives, oral rehydration therapy, drug abuse and heart disease.

The term NGO is broad and ambiguous. It covers a range of organizations within civil society, from political action groups to sports clubs. It's clear definition still contested. The concept of NGO came into use in 1945 following the establishment of the United Nations organizations which recognize the need to give constructive role to organization which was classified as neither government nor member states (willett, 2002).

The acronym 'NGO' has become part of everyday language in many countries. It has entered in the vocabulary of professionals, activists and that of ordinary citizens. NGOs have recognized as important element in development from reconstruction efforts in Indonesia, India, Thailand and Sri Lanka after the 2004 Tsunami disaster to international campaigns for aid and trade reforms such as 'make poverty history'.

Non government organizations are nonprofit organizations that are not directly associated with government and work for social or environmental purposes. NGOs can be divided into two type of organizations.

- $\quad$ Collaborative NGOs which primary purpose is to design and implement development project through stakeholder engagement and

- $\quad$ Campaigning NGOs which primary purpose is to defend or promote a specific course through lobbing activities (CBI).

NGOs emerged into the development limelight but they are not a recent phenomenon. They were the earliest form of human organizations. Long before the governments, people organized themselves into group for mutual protection and self help. First, there were farmer's organization as in Japan in 1868; such organizations played a vital role in agriculture movement. Traditional self help associations have also a long history in Africa and Asia. 
During the $18^{\text {th }}$ and $17^{\text {th }}$ centuries in particular there has been an explosion in the number of NGOs and an upsurge for the realistic answers to problem over a king of neglected issues related to ecological degradation, rights of people and other common property resources appropriate technologies, health, safety, gender and equity. The institutional forms of such organizations can be traced back in late $19^{\text {th }}$ and early $20^{\text {th }}$ centuries particularly in west world where the history of social organizations seems to have been largely influenced by "laisser fair" movement based on a more planned way.

\section{Aims and Objectives of NGOs}

Non-government organizations have different aims and objective, from which some common aims and objectives are:

- To organize awareness campaign amongst the local people about the general diseases and their prevention.

- To organize campaign against the practices of female feticide and for the promotion of adolescents reproductive health.

- To establish medical institute to impart training in various disciplines i.e. diploma in lab, X-Ray technology etc.

- $\quad$ To make the community aware of relevance and importance of respect for each other, humanity and cooperation.

- $\quad$ To promote sports and youth co-ordination activities among the educated boys/ girls living in rural / urban slum areas.

- To promote environmental and pollution control awareness by seminars, workshops, camps and arrangement of training classes for rural people living in far flung areas.

- $\quad$ To provide drinking water resources, low cost sanitation facilities and construction of low cost house for peoples living below poverty line under JRY and other schemes.

\section{Objectives:}

1. To study the consumer's awareness of NGOs activities.

2. To know the perception of consumers of NGOs activities.

3. To understand the concept of social marketing.

\section{Research Methodology:}

Sample of 200 respondents have been taken through convenient sampling for this study. The sample consists of respondents of different age groups and having different educational background from the three districts Karnal, Kurukshetra and Kaithal of Haryana. Data has been collected through questionnaire.

\section{Analysis of Data}

The target 200 audiences included both male and female groups. Table1 shows that out of total respondents $61 \%$ are male and $39 \%$ are female. It indicates that major proportion of respondents is male.

Table 1: Frequency Distribution on Gender basis

\begin{tabular}{|l|l|l|}
\hline Gender & Frequency & Percentage \\
\hline Male & 122 & 61.0 \\
\hline Female & 78 & 39.0 \\
\hline Total & 200 & 100.0 \\
\hline
\end{tabular}

On the basis of residential status

Table2 Frequency Distribution basis on Residential Status

\begin{tabular}{|l|l|l|}
\hline Residential Status & Frequency & Percentage \\
\hline Rural & 127 & 63.5 \\
\hline Urban & 73 & 36.5 \\
\hline Total & 200 & 100.0 \\
\hline
\end{tabular}

Table 2 shows that out of total respondent $63.5 \%$ are rural and $36.5 \%$ are urban. It indicates that major proportion of respondent is of rural background.

\section{Respondents Awareness of NGOs}

Number of NGOs is existing in one area. Many times it has been observed that the people are not aware about NGOs or their activities. Therefore in this study an attempt has been made to know the respondent awareness of NGO. Table 3 highlights that $53.5 \%$ of respondents are aware about NGOs and $24 \%$ are aware 
about 3-5NGOs in their areas. However $8 \%$ are not aware about the existence of NGOs in their areas. So we can say that majority of respondents are aware about NGOs.

Table 3: Frequency Distribution on Awareness of NGOs

\begin{tabular}{|l|l|l|}
\hline Variables & Frequency & Percentage \\
\hline Less than 3 & 107 & 53.5 \\
\hline 3 to 5 & 48 & 24.0 \\
\hline More than 5 & 29 & 14.5 \\
\hline Don't know & 16 & 8.0 \\
\hline Total & 200 & 100.0 \\
\hline
\end{tabular}

\section{Attachment with NGOs}

To find out the attachment of respondents with any NGOs, the collected data has been summarized in the form of percentage.

Table 4: Attachment with NGOs

\begin{tabular}{|l|l|l|}
\hline Variables & Frequency & Percentage \\
\hline Yes & 62 & 31.0 \\
\hline Sometimes & 65 & 32.5 \\
\hline No & 73 & 36.5 \\
\hline Total & 200 & 100 \\
\hline
\end{tabular}

The table indicates that $31 \%$ respondents are attached with NGOs and $32.5 \%$ respondents are attached for sometimes, might be for a project/program. However it may be because of the reason of not having any interest in NGOs activities. Therefore it can be concluded that most of people are not attached with NGOs permanently.

\section{Source of information about NGOs}

What is the source of information from where people get information about NGOs is also an important question to be asked from respondents.

By going through the table number 5 it is found that $56 \%$ respondents are getting information directly from NGOs. It may be employees, members, volunteers etc of NGOs. 33.5\% respondents get information from media and $35.5 \%$ from their friends. So conclusively it can be said that the main source of information is NGO itself, because number of volunteers are attached with NGOs.

Table 5: Sources of Information about NGOs

\begin{tabular}{|l|l|l|}
\hline Sources & Frequency & Percentage \\
\hline Directly from NGOs & 112 & 56.0 \\
\hline From media & 66 & 33.5 \\
\hline From friends & 91 & 35.5 \\
\hline
\end{tabular}

\section{Conclusion}

In the present study an attempt has been made to study the social marketing of NGOs. There are different types of activities being undertaken by the NGOs for consumer awareness. These activities spread awareness for social welfare, therefore involved in social marketing. It has been found that respondents are mostly aware about the NGOs. Most of them are not associated with NGOs permanently. Some are not associated with NGOs due to lack of time. However, some respondents are associated for a short time and some are found associated for long time or we can say permanently. Those who are associated permanently may be the employees of NGOs, volunteers etc. The analysis reveals that major source of information about NGOs is direct information provided by NGOs. Different sources like media, friends, any other are also playing an important role to spread information about NGOs.

\section{References}

[1]. Kotler, P. Zaltman, G. (1971). Social marketing: an approach to planned social change. Journal of marketing, Pp3-12.

[2]. Lawther, S. and Lowry, R. (1995). Social marketing and behavior change among professionals, social marketing quarterly, pp10-11.

[3]. Lovelock, et al., (1989). Marketing for public and nonprofit managers ( $2^{\text {nd }}$ ed.). redwood city, C.A : the scientific press, 1989.

[4]. Nelson, J., (2007). The operation of non-government operations in a world of corporate and other codes of conduct. Corporate social responsibility initiative, working paper no.34, pp1-35.

[5]. Rados, David,. (1996). Marketing for non-profit organizations ( $2^{\text {nd }}$ ed.). boston: aubum house publication company.

[6]. Marchese, S.G., (2011). Raising awareness and donations for NGOs through digital and social media. Global coalition for hearing health second annual conference.

[7]. Lewis, D. and Mensah, P. (2006). Moving forward research agenda on international NGOs: theory, agency and context. Journal of international development, vol.18, pp665-675. 